DOI https://doi.org/10.30525/978-9934-26-039-1-66

\title{
TO THE QUESTION OF EXPRESSIVE-EMOTIONAL CHARACTER OF YOUTH LANGUAGE
}

\author{
Rudenko M. Yu. \\ Candidate of Philological Sciences, \\ Assistant Professor at the Department of German and Slavonic Philology \\ Donbas State Pedagogical University \\ Slavyansk, Donetsk region, Ukraine
}

The special feature of modern youth language is its polyfunctionality. It executes both general linguistical and specific functions, inherent only to it. Among them: representative/identifying/signal, recognizing, communicative, emotional-expressive, nominative, secret, ideological, corporate, function of (so called) psychological relief and others. In its turn, functions of youth language identify essence, peculiarities and reasons of origin and functioning of youth speech units in many ways. However during the communication process it is not always possible clearly to define boundaries each of these functions. Frequently they are combined [2, p. 83].

Let's apply to the peculiarities of emotional-expressive function, that has important value in youth language. The function is connected with showing emotions, feelings, moods, expressing the attitude and correspondding assessment. It is considered to be the main function of slang. V. M. Mokiyenko (2010) notices, that jargons attract the youth by their expressiveness and imagery. Without them the speech is too boring.

The examples of expressive slang can be seen in many languages, moreover they are often equivalent. V. Kulikova (2013), for example, marks the existence equivalent expressive slang in youth French and Ukrainian slang: chetron ( $m)$, berlingot ( $m$ ), balle $(f)$ - scoreboard, puck, hollow, creator, pack, muzzle, phiz (head, face); bouts de bois ( $m, p l)$, canne $(f, p l)$-flippers, hooves, pistons (legs); bidon $(m)$ - hole, cast (belly); orbites ( $f, p l)$ - bathes, headlights (eyes) and others.

M. A. Grachov (2006) pays attention to the functioning of general youth jargon, that is used by all youth unions and groupings. It consists of words, that are not connected with the process of study, labor, military service and others. Its base is expressive equivalents of colloquial vocabulary.

Slang is characterized by special emotional saturation. M. A. Kropachova (2011), marking a high proportion of emotional and evaluative vocabulary in student jargon, as a result of expressive function of youth jargon, pays 
attention to prevalence vocabulary, that expresses negative mark of reality. E. E. Matyushenko describes youth vocabulary as genetically heterogeneous, which is characterized by negative emotionally expressive valuation (disapproval, neglect, contempt, humiliation) [2, p. 163-164].

V. D. Bondaletov (1987), P. Ondrus (1975) pay attention to the expressiveness of student, school jargon. Slang of pupils, students differs by abundance of expressive synonyms with high connotation. For example: head - chump, bonce, timbrel, kettle, attic and others; face - signboard, murlo, face, pack, snout and others; nose - cutout, schnobel, sniffer and others.

Young people don't close expressive vocabulary in themselves, they spread it widely. From general youth jargon expressive vocabulary is borrowed by different subcultural slangs. So, in slang of extremal sportsmen V. R. Khalikova underlines the words, expressing accordingly positive or negative assessment: kaif/kaify, rulis, drop dead, normalds, loot, and offset (well done trick, praise), incendiary; fiasco, murder, meat, splashing, crap, stupak, loose, indent, rubbish and others.

As an expressive element, that forms «stylistic scrapping» (term by $\mathrm{Yu}$. M. Lotman), slang is effectively used in microdoses both in prose and in poetry. The attractiveness of slang units as a brief emotionally-expressive stylistic mean causes their usage also in the advert. «Don't break - have Snickers!» - the advertisement - the advertisement of the chocolate «Snickers» (to break - «to think slowly, not to understand») [2, p. 37-38].

M. Yu. Rossikhina (2009) notices, that youth vocabulary is subjected by the changing of semantics, expression during the determined time. For example, the word pops in 1970-s had a positive connotation (pops - something modern, popular; pop-music $=$ rock-music), although in 1980-1990-s it received negative stylistic shade (pops - something connected with mass culture, opposite real art. Low-grade pop music).

According to D. V. Gromova (2009), special emotionality, tendency to ecstatic states is peculiar to adolescence. Due to this there is much amount of words (about 20\%), that express a high degree of emotional assessment in general youth slang (Wow! Atas! Kaif! Cool!; to wallow, to spark, to a-shake; indent, low-rep, beard and others).

Youth vocabulary is close to poetry language. Thought of similarity of poetry language and slang is expressed by Dutch linguist Otto Yespersen. The scientist has noticed, that slang is frisky and eccentric language. This is a peculiar game, where the new appears there, where peculiar there is no need in the new and new expressions near the old ones make the function of emotional diversity [3, s. 234]. It is obvious, that humor and rough emotion dominate in youth jargon. It depicts, as L. Masenko (2010) writes, peculiar to youth 
environment position - «if only it was different and funnier, than in ordinary speech», that is, aimed at game, entertainment.

Undoubtedly, that one of the main expressive shades, that has slang vocabulary, is humorous one. Sometimes in emotional color of slang the emotion of fun not only exists, but dominates. According to E. Partridge (1935), slang is so-called challenge to boredom and inexpressiveness in the language; it is a language of hints. But «slang in rare cases or even never is cruel in its hinting assessment, it puts things on their own places with grin».

O. V. Blagoveshchenskaya (2007) notes, that the main aim of creation of new units in youth jargon is the aspiration to make the speech more expressive and original. "Youth word formation», from one side, is done in the frames of language system and depicts the processes that are in nationwide language, from another side - it discovers the features, that are not peculiar to standard language. According to L. P. Krysin, «linguistic essence of all varieties of youth slang is the same: game with word and in word, metaphorization of word meanings to create expressive, emotionally colored means of linguistic expression» [1, p. 76]. Due to this O. V. Blagoveshchenskaya (2007) also writes: «The tendency to make speech more expressive and original is shown, in particular, in wide usage of pan - such phonetical and morphological ways, as using wordplay, «imitation», contamination, metathesis, etc. Thereby a lot of realities in «youth language» get parody-laughter interpretation».

Youth language executes both general linguistic and specific functions, inherent only to it. One of the main functions of youth language is emotionally-expressive one. Vocabulary and phraseology of the youth language is highly expressive (compared to general literary standard). The youth is extremely emotional, prone to ecstatic. Exactly this explains the presence in general youth language a huge amount of words, expressing a high level of emotional assessment.

\section{References:}

1. Krysin L. P. Sociolinguistic aspects of studying the modern Russian language. Moscow : Science, 1989. 188 p.

2. Matyushenko E. E. Modern youth slang: formation and functioning : The dissertation of the candidate of philological sciences : 10.02.01. Volgograd, 2007. $188 \mathrm{p}$.

3. Grabias S. Ši zawodowe odmiany je socjolekty. Encyklopedia kultury polskiej XX wieku. Wroclaw : Wiedza o kulturze, 1993. T. 2. S. 223-241. 